\title{
Ultrasonic echography for early pregnancy diagnosis in sows
}

\author{
O. BOTERO *, Françoise MARTINAT-BOTTE *, Françoise CHEVALIER ** \\ * I.T.P., 149, rue de Bercy, 75595 Paris Cedex 12 \\ *:I.N.R.A., Station de Physiologie de la Reproduction, Nouzilly, 37380 Monnaie
}

France

In human medecine, ultrasonic echography may be used to explore abdominal organs without harming the urogenital structures. Application of this technique in the sow required determination of the optimal testing site, interpretation of the images obtained and verification of the diagnosis.

A total of 30 sows of different breeds and parities were examined every 2 or 3 days from day 18 to day 30 after insemination. The probe was placed on the skin of the animal between the first and the third posterior teats and the bladder, the vagina and the uterus could be seen. The black areas corresponded to structures full of liquid which do not emit any echo, and the grey zones corresponded to tissues. The diagnosis was checked by returns to oestrus for non-pregnant animals and by slaughter for the pregnant ones.

In non-pregnant sows the genital tract appeared as an echogenic tissuc of heterogeneous nature. Eighten days after insemination the embryonic vesicles appeared as more or less spherical black patches against the echogenic tissue of the uterine wall. The pregnancy diagnosis obtained by echography was reliable in $95.6 \mathrm{p}$. 100 of the cases as confirmed by slaughter. None of the animals that displayed oestrus behaviour 25 days after insemination were diagnosed as prcgnant by echography. Thus, the non-pregnancy test exhibited a 100 p. 100 accuracy. For females in which oestrus occurred more than 25 days after breeding, the accuracy of the non-pregnancy test fell to $21 \mathrm{p} .100$, this being presumably due to embryonic mortality.

\section{V. - PATHOLOGY}

\section{Present knowledge on Aujeszky's disease}

\author{
P. VANNIER \\ Ministère de l'Agriculture, Direction de la Qualité, Services Vétérinaires, \\ Station de la Pathologie porcine, B.P. 9, 22440 Ploufragan
}

France

A comprehensive revicw is made on Aujeszky's disease including a study of the virus morphology and its environmental resistance as well as the pathogenic power of the various strains isolated up to now. Results of recent epidemiological inquiries are used to analyse the present situation in France. According to these studies, mainly the pig is responsible for the dissemination of the virus. There are two possible situations, i.e. areas with a low pig herd density and areas with a high pig herd density. In the latter case, the air borne transmission of the virus seems to be predominant. After a clinical study of the disease in the pig and in other species, an analysis is made of the main techniques of diagnosis as well as medical and sanitary prophylaxis. Recent French regulation concerning prevention of Aujeszky's disease is examined. 